\title{
From Complexity to Fear and Optimism in Everyday Life With COVID-19
}

\author{
Plamen A. Atanasov \\ Sofia Universiry 'St. Kliment Ohridski' \\ От комплексност към страх и оптимизъм в COVID-19 \\ ежедневието \\ Пламен А. Атанасов \\ Софийски университет „Св. Климент Охридски"
}

\begin{abstract}
Author Note
Plamen Atanasov

https://orcid.org/0000-0003-3926-337X

The author has no known conflict of interest to disclose.

Correspondence concerning this article should be addressed to Plamen A. Atanasov
\end{abstract} E-mail: atanasovp@abv.bg

\section{Бележки за автора}

Пламен Атанасов

https://orcid.org/0000-0003-3926-337X

Авторьт няма конфликт на интереси.

Кореспонденцията, във връзка с тази статия да се адресира до Пламен А. Атанасов E-mail: atanasovp@abv.bg 
Abstract
The COVID-19 pandemic of 2020 developed into a crisis of civilizational type. The interactions within society are more complicated: the present is high complexity, apparent confusion, low social trust levels, and fear among people. This leads to conspiracy theories and behavioural infections ranging from depressions to aggression, while simultaneously, it creates the need for hope and optimism. The paper aims to show that overcoming the social estrangement and balancing fear with optimism and hope is essential for the future of social reality. The paper utilizes existing scientific developments from the fields of psychology, sociology, and the media and publicly available articles from the mass media. Based on them is defined the problem which is set out as the consequence of unresolved matters around the neoliberalism which is infiltrating the social interactions; the fear and the conspiracy theories, and the poorly understood need for optimism and hope. The focus is also set on these problems entering the mass media, where the situation is unusual, as far as the fear of COVID-19 is concerned. In these circumstances, both society and the media must evaluate their attitude towards neoliberal policies and find their balance between fear and the need for hope.

Keywords: COVID-19 crisis; neoliberalism; fear; hope; mass media

\section{Резюме}

Пандемията, причинена от вируса COVID-19 прерасна през 2020 г. в криза с цивилизационен характер. Отношенията в обществото са усложнени, т.е. с висока комплексност. Объркването е високо, общественото доверие - ниско, а сред хората страхът е видим. Той води до конспиративни „теории", до поведенчески изкривявания в спектьра от депресии до агресия и в същото време поражда необходимостта от надежда и оптимизъм. Целта на настоящата статия е да покаже, че преодоляването на социалната изолираност и балансирането на страха с оптимизъм и надежда са определящи за бъдещето на социалната действителност. В статията са използвани съществуващи научни разработки в областта на психологията, социологията и медиите, както и достьпни публикации в масмедиите. На тази основа е изведена проблематика, която е определена като плод на нерешени въпроси около проникването на неолиберализъм в обществените отношения, на страха и конспиративните теории и на недобре решената потребност от оптимизъм и надежда. Фокусът е насочен и към проникването на тези проблеми в масмедиите, където ситуацията е необичайна по отношение на страха от коронавируса. При тези обстоятелства и за обществото, и за 
медиите е определящо да решат ценностното си отношение към неолибералните политики и да изберат баланса между страха и потребността от надежда.

Ключови думи: COVID-19 криза, неолиберализъм, страх, надежда, масмедии

ARTICLE INFO:

Original Article

Received: 05, 09.2020

Revised: 15, 09.2020

Accepted: 02, 11.2020 


\section{Въведение}

В края на 2019 г. в провинция Ухан в Китай се появи нов вирус - COVID-19. Днес, вече почти година, светът е в пандемия. Наложени са ограничителни мерки върху публичния живот, здравната система на не една държава е претоварена, науката все още изследва вируса, а в публичното пространство се ширят всякакви обосновани и необосновани идеи за справяне с пандемията, както и конспиративни „теории".

Общественият живот е променен и в значителна част от сферите си - усложнен. Приемаме обстоятелството като степен на повишена (над обичайното) комплексност в отношенията на всички социални равнища. Оформя се веригата, че това усложняване води до спад в общественото доверие, до объркване, включващо агресия и ментално бягство в конспиративни теории, както и специфичен страх, а този страх поражда необходимостта от надежда и оптимизъм. По силата на показаната последователност, медиите попадат в условия на необичайно повишен обмен и търсене на информация, но освен страх, в тях трудно се откриват ясни визии за доверие и надежда в бъдещето, което следва след пандемията. Тази литота свързваме с нерационалността на отношението към неолибералните политики, с ниската подготвеност за биологични заплахи и към подценяването на ефектите от тоталното избягване на контакти по време на пандемията, довело до социална уязвимост на индивидуално и масово равнище.

В такъв план, целта на настоящата статия е да покаже, че триадата страх доверие - надежда е определяща за балансираното представяне на социалната действителност и за ефекта от работата на медиите. Разрешението на тези два проблема е определящо за бъдещия облик на масмедиите, както и за бъдещия облик на масовите възприятия, нагласи и настроения.

Проблемът е в онова, че медиите предават случващото се в обществото, а относно COVID-19, днес - в края на 2020-та година е наличен предимно страх. Проблематиката е разбирана като плод на превалирането на неолибералните разбирания в Европа, САЩ, а от там и в по-голямата част от света. В резултат днешната публичност подлага на силно съмнение доверието, разбирано в духа на вижданията на Никълъс Луман, като намаляване на комплексността (сложността) в обществените отношения. В същото време в масовия взор остават твърде мъгляви очертанията на надежда и оптимизъм. Надежда и оптимизъм в чисто психологическия им смисъл на устрем към позитивен резултат и емоция. Доверието, че институциите се справят по най-добрия начин с пандемията и надеждата, че светът ще се промени към по-добро, към края на 
2020 г. все още са силно неясни. Пренасянето на тази чисто психологическа материя в социално доминираното по същността си пространство на обществените отношения показва, че днешната публичност е изправена пред тематичен недостиг: Страхът от вируса е навсякъде и повишава търсенето на медийните съобщения, но там аудиторията не намира достатъчно ясно очертани доверие и надежда, с които да бъде уравновесен въпросният страх. Това поставя медиите в специфична ситуация на изчакване на развръзка.

Актуалността на връзката между изброените проблеми и пост-COVID-19 действителността не подлежи на съмнение. Това, че вирусът ще отмине, а хората ще останат, е вярно и точно тази вяра определя настоящата COVID-19 криза като далече по-мащабна от една криза в здравеопазването, била тя и в световен мащаб. Болниците и лекарските кабинети не смогват, хората не знаят как ще изглежда животьт им занапред. Едва ли съществуват съмнения, че по света няма човек, който да желае такова настояще и евентуално бъдеще.

Разработката е насочена към отражението на COVID-19-кризата на макроравнище, т.е. към обществото. Критерият за разделяне на микро- и макро- е наличието или отсъствието на опосредстваност в контактите между членовете на социалното формирование. В макро-групите контактите са опосредствани, а в микро - не. (Dzhonev, 2013, p.41) В мезо-агрегатите е прието, че се ползват и двата типа. Фокусьт на изследването е поставен върху призмата на социалната роля на медиите и то в пресечната точка между еволюционистичната перспектива в психологията и философските концепции за предстоящото. Използвани са съществуващи научни разработки и публикации в медиите. Напрегнатостта на отношенията е представена според вижданията на съвременни философи за последиците от разбирането за неолиберализъм, навлязло в отношенията през последните две-три десетилетия. Така са очертани, доколкото е възможно, и евентуалните пътища, които ще отведат обществото към желаната визия на преодолени икономически сривове, на по-висока сигурност пред биологичните заплахи и на по-ефективни медии, чиито съобщения ориентират за случващото се в заобикалящия социален свят.

При използването на такъв подход е съобразено и наличието на съпътстващи трудности. Намираме се в окото на цивилизационна криза, предизвикана от пандемията COVID-19. В такъв момент обобщаването на емпирични данни е затруднено. Причината е в съмнението, че хората са объркани и масовите нагласи са особено 
чувствителни. Както показва обстановката и в Европа - настроенията бързо се променят в целия спектьр от спокойствие до висока напрегнатост. Тази интензивна променливост компрометира отнасянето на резултатите към макро-социални обобщения дори и към близък момент.

\section{Липса на готовност за реакция срещу биологични заплахи. Комплексност в отношенията}

Появата на вируса COVID-19 (Sars-CoV-2) припомни за научното късогледство в това да се мисли, че са известни всички вируси, бацили, акари и други, които са патогенни за човека и представляват заплаха. По силата на еволюционната обусловеност човечеството съществува, защото поема риска от съвместния живот с тях. C развитието на знанията хората намаляват този риск, но едва ли могат да го елиминират (защото не само човешкият вид се развива). Колкото повече знания натрупваме, толкова по-дълбоко навлизаме в света и толкова повече научаваме за него. В същото време вирусът показа, че това не са само теоретични обобщения, а и практическо положение, което изисква съответната подготовка, която в случая на настоящата пандемия явно не е на нивото на публичните очаквания. Така е и у нас, и по света. Показват го заглавия като: „ Хиляди в Лондон: COVID-19 е конспирация. Според протестиращите маските намаляват имунитета" (Kirov, 2020b); „Опит за щурм на Райхстага, стотици арестувани" (Kirov, 2020c); „Социолог: Българите са разделени относно мерките за COVID-19"("Sociologist: The Bulgarians are divided about COVID-19 measures", 2020) и др.

Объркването е голямо, а светът е променен. Темите за фалшивите болнични ("Dr Branzalov: Fake sick leave no", 2020) и дебатите около въпроса трябва ли за всяко кихане да се ходи на лекар, постепенно се трансформираха под мотото „дайте да пазим здравето". Явно пандемията реализира далече по-мащабна криза от тази в здравеопазването. Противопоставянето сред хората не само остана, но и доби стилизирания вид на алтернативата между черно и бяло. То се конкретизира в дебати „за" и „против". „За" и „против" носенето на маски, „за" и „против" пътуването и свободното придвижване на гражданите, „за" и „против" светенето с мобилни телефони пред болниците, „за" и „против" ръкопляскането по балконите и т.н., а истинската причина за това лутане сред изкуствени алтернативи намираме в „заметените тайни" преди идването на вируса. 
Объркването води до още по-сложни отношения. Според Никълас Луман, известен с комуникационната си концепция, че определяща роля изпълняват връзките в мрежата от комуникатори, тази сложност на обществените отношения е обвързана с общественото доверие. Причината е, че самото обществено доверие е конструкт, който служи за намаляване на комплексността (която авторът разбира и като сложност) в обществените отношения. (Luhmann, 2014)

По тази причина и във връзка с повишената комплексност въпросът за доверието е превърнат в една от злободневните теми в обществения дневен ред. Търсим доверие към лекарите, към институциите, към останалите и т.н., а по същността си това е израз на инстинктивния човешки стремеж към намаляване на сложността в отнасянето към другите.

Повишената комплексност е в основата и на удивлението, че COVID-19 „изненада" човечеството с пандемия. Това, че светът не е подготвен за заплахи от биологично естество, е известно отдавна. Още през 2015 г. Бил Гейтс прави изявление на конференция на TED (Technology, Entertainment, Design - американски частен нетърговски фонд за оригинални идеи), че най-голямата опасност за човечеството не е ядрената война, а смъртоносен вирус (Stepanova, 2020). Подобна констатация прави и икономистьт Клаус Шваб - председател на Световния икономически форум в Давос, в книгата си „Индустрия 4.0", издадена през 2106 г. (Schwab, 2016, p. 44). Едно от последите напомняния преди пандемията е от симпозиумът на университета „Джонс Хопкинс", проведен на 18 октомври 2019 г. съвместно с Фондацията на Мелинда и Бил Гейтс и със Световния икономически форум. На тази среща се провежда управленска симулация на реакциите в „разгара на неконтролируемо избухване на коронавирус, който се разпространява толкова лесно, колкото пожар в Южна Америка и причинява световен хаос....имунорезистентният вирус, наречен CAPS, блокира тьрговията и пътешествията и привежда световната икономика в състояние на световно падане. Социалните мрежи са препълнени със слухове и дезинформация.... правителствата падат, а гражданите се бунтуват" (Pearce, 2019).

Изводът е: „ние далече не сме подготвени" (Pearce, 2019). Цитатът е от месец ноември 2019 г., когато светьт още не е чувал за COVID-19.

\section{Естеството на проблемите}


Без съмнение хората са изправени пред цивилизационен проблем. Пандемията COVID19 е само поводът за почистване „до блясък" на отдавна замитани и покрити с прах неприятни теми за отлагани обществени реакции.

\section{Неолибералните изкривявания в обществото}

Нещо повече - не без помощта на неподготвеността и натрупваните с годините позиции, че биологичната заплаха няма да е случи - вирусът COVID-19 предизвиква ескалация на напрежението през месец март на 2020 г., но не е овладян, а действието му продължава. През това време навсякъде по света работят съответните институции, но при следващата вълна здравната система се оказва претоварена и с куп „изненади". Този факт се превръща в актуален проблем за ежедневието и показва, че философското търсене още от началото на пандемията съвсем точно се е фокусирало върху темата. В една съществена част постигнатите умозаключения разкриват, че проблемът не е в съществуването на вируса COVID-19, а в отдавна „замитаните под килима" компромиси. Компромиси, които според някои съвременни философи носят чертите на безкритично допуснати промени от неолиберален характер.

В статията терминът „неолиберализъм" е свързван по-скоро с проблем, отколкото със строга дефиниция. Това е едно разпространено схващане, което автори от Станфордския университет описват като противоречието между пазара и моралните движещи сили на на частната собственост в икономиката. Като активни фактори за това обобщение са разбирани три посоки на новост в политиките: 1) съмнението, че либералното отношение към пазара е основа за устойчиви обществени отношения; 2) неизвестността до каква степен либерално доминираната правителствена намеса в пазарите е в синхрон с обществото (въпрос, който, въпреки десетилетните спорове, и до днес не е с ясен отговор в публичността); 3) ,растящото убеждение, че правата на собственост не се явяват „защитник на всички права" (Ely, 1992)". (Gaus et al., 1996)

Тези уточнения разсейват съмнението, че пандемията COVID-19 е криза само от здравен характер. В интервю, проведено от Ю. Чекалин, Ноам Чомски - известният съвременен философ, политолог и лингвист определя причиненото от коронавируса като „криза на цивилизацията"(Chekalin, 2020). Като основно противоречие е определено виждането за разминаването между реалността и неолибералните политики, насочени към налагане на пазарни подходи, ориентирани към максимализиране на печалбата без оглед правата и потребностите на обществото. Ето какво казва Чомски: 
„Ние сериозно трябва да помислим какво ни показа коронавирусът. На първо място - това е колосалният провал на пазарите.... живеем в атмосфера на идеология, за която голяма част от отговорността носят икономистите. Идеология, установена още от Роналд Рейгън, с прочитането на текста, написан от неговите корпоративни хазяи, в който се казва, че правителството е главният проблем. Лозунгът „Дайте да свършим с правителството!" означава предаване на властта на частни тирани, тези, които не носят никаква отговорност пред хората. Ние получихме прости хора, хвърлени в пазара, хора, на които са предоставили възможността да спасят сами себе и по някакъв начин. Така беше с десетилетия и въпреки че днес съществува забележителна възможност това да се поправи, тя се оказва блокирана поради идеологически предразсъдъци" (Chekalin, 2020).

Освен неолиберализма и обвързването му с икономиката, Н. Чомски посочва още една причина - социалната изолация, но не тази поради карантинирането. Философът подчертава, че изолирането на човека е видимо през последното десетилетие, както е видимо и, че се дължи на навлизането на интернет и намесването на компютърното опосредстване в общуването (Atanasov, 2017). Според Н. Чомски съвременната информационна свързаност ,атомизира и изолира хората до такава степен, че обществото вече не съществува". В тази посока философът вижда основната задача на предстоящото, като „да се помогне на хората да се съберат по всякакъв възможен начин. [...] Разбира се, след карантината" (Chekalin, 2020).

Едно различно виждане за достигането на днешното положение представя и авторитетният финансист, известен с философските си заключения в защита на глобализма Жак Атали. В своя блог той поставя акцент върху върховенството а закона. Ж. Атали пише:

„Съвременната държава, подобно на духа на науката, се роди като следствие, като ударна вълна, от тази огромна здравна трагедия. И двете всъщност препращат към един и същ източник: съмнение в религиозния и политически авторитет на църквата, неспособна да спаси живот или да даде смисъл на смъртта. По този начин полицаят замени свещеника.

По същия начин в края на 18 век лекарят заменя полицията като най-ефективната крепост срещу смъртта. 
Така че в продължение на няколко века ние се преместихме от власт, основана на вяра, до власт, основана на уважение към използването на сила, а след това към поефективна власт, основана на зачитане на върховенството на закона" (Attali, 2020).

На фона на тези изказвания се вижда, че неолибералната идеология е навлязла дълбоко и у нас. Заглавия като: „САЩ изкупиха всичкия „Ремдесивир" за COVID-19. Те ще получат всички бройки, произведени през юли" (Kirov, 2020a); „Сигнали за липса на „Ремдесевир" в болниците в София и Враца" ("Reports of shortage of Remdesivir in hospitals in Sofia and Vratsa", 2020); „Скандал с даряването на крьвна плазма за Ковид19" ("Scandal with the donation of blood plasma for COVID-19", 2020) или „Шефьт на БЛС за COVID-19: Обществото се провали" ("Head of the Bulgarian Medical Union: Society failed ", 2020) показват, че съмненията, предизвикват скандали и противоречиви действия и още повече объркват обществото.

Вероятно най-атрактивен случай за проникването на неолибералните противоречия е от времето на пролетната ескалация на напрежението около COVID-19. Тогава обществото реагира срещу идеята за дарение на апарати за командно дишане, но с условието те да са за семействата на собствениците и за служителите на фирмите дарителки. В конфликта се разкриват и моралните дисонанси. От Александровска болница връщат опита за дарение (името на фирмата и собственика съзнателно не е споменавано). ("After the returned donation, "Utopia" bumps up the amount of money and the machines", 2020) Странната проява на неолиберализъм, разбирана като: ще ползвам обществения договор, но ще поддържам само онова, което носи изгода, продължава с идеята, че: „Ако и други купят апарати за изкуствено дишане, няма да има оставени без помощ" ("Ivajlo Penchev: If others purchase respirators too, everyone will be taken care of", 2020). Само, че „другите" са не по-различна част от обществото и обществените проблеми не се решават чрез чакане някога и някак си. Все пак, в обществото всички пациенти са равни. COVID-19 особено красноречиво припомни, че равенството е важно и че не всичко може да се купи на момента. Например здраве, лекари и медицински сестри.

\section{Конспиративните теории}

В тези условия съвсем не е изненадващо циркулирането на конспиративни „теории" в публичното говорене. Едно собствено изследване (Atanasov, 2020) върху дискусията в популярния форум БГ Мама, известен с това, че в него пишат всякакви хора (жени, мъже, млади, възрастни, с различни професии, живеещи в различни 
държави) показва, че още в първите дни на пандемията, през м. февруари и март, се очертават следите фабули:

- биологично оръжие срещу възрастните;

- води се хибридна война: - от страна на Китай или срещу Китай (срещат се и двете твърдения);

- тьрси се печалба за фармацевтичния бизнес;

- богатите оцеляват за сметка на бедните;

- влиянието на 5G системата. (Atanasov, 2020)

Подобни теми се откриват и в социологическо изследване, проведено от независимата социологическа агенция Тренд по поръчка на в. „24 часа" и публикувано на страницата на агенцията. В него са включени 1008 преки нестандартизирани интервюта от типа „лице в лице". Темата на изследването е „Нагласи на българите спрямо коронавируса и конспиративни теории (юни 2020)". От споменатото изследване става ясно, че основните конспиративни теми са:

- 5 G технологията;

- биологично оръжие за намаляване на населението на Земята;

- световна измама;

- с евентуалната ваксина ще се имплантират чипове за контрол над индивида;

- Бил Гейтс стои в основата на пандемията;

- фармацевтичната индустрия търси печалби.

Публикуваните на страницата на ТРЕНД данни показват, че 2,3 млн. от пълнолетното население у нас вярва, че вирусът е създаден изкуствено. ("Тhe Bulgarians' attitude towards COVID-19 and conspiracy theories", 2020)

Близостта във фабулите, регистрирани в двете изследвания, позволява не само заключението, че конспиративните теории съществуват и че са относително постоянни, но и очертава тяхната тематична рамка.

Положението по света не е по-различно. Споменатият вече материал със заглавие „Злодей за конспиролозите, филантроп, втори в списька на Forbes. Бил Гейтс на 65 години" (Stepanova, 2020) показва, че конспиративните теории са забелязани и в други страни.

Приемът на такива хомогенни и устойчиви конспиративни „теории" в публичността е индикатор за тежки поражения от социален, икономически и здравен характер. Например от Офиса на Световната здравна организация (С3О) в България 
свързват склонността към конспиративизъм с отказа на хората да бъдат ваксинирани. Според представляващия СЗО в България 37\% от анкетираните в рамките на изследване на Организацията за нагласите и настроенията на българите по време на криза, не искат да бъдат ваксинирани срещу коронавируса. Като причина за този странен резултат сочи мнителността и скептицизма на хората. Според данните $62 \%$ от хората изпитват страх, а $60 \%$ безпомощност. ("Assoc. Prof. Okoliiski, "37\% of Bulgarians do not want to be vaccinated against COVID-19." According to him, this results from false beliefs and conspiracy theories, 2020)

Връзката със страха и безпомощността е ясна - още през втората половина на 20-ти век Мартин Селигман прави една от първите дефинирания на депресията като я определя с краткия израз: „заучена безпомощност" (Seligman, 1975), а и без научна подготвеност се вижда, че между депресията, тревожността и страха психологичното разстояние не е голямо.

От гледна точка на настоящата проблематика битуващата широка конспиративна убеденост е приета като израз на страх. Свързваме я с потенциране на усещането за страх (индивидът се самоубеждава в страстта си) или с опити за бягство от страха.

\section{Страхът, оптимизмът и агресията}

Страхът е разбиран в еволюционистичното му значение - като адаптацонен механизъм за приспособяване към средата чрез противодействие на опасностите (Goleman, 2011, p.15). От гледна точка на еволюцията страхът е адаптационен механизъм. Човекът и по-висшите животни се страхуват, като „усещат" заплахите и така избягват неблагоприятни свои действия. (Moller \&Nielsen, 2010; Ciuti et all., 2012) При човека адаптационните механизми към заобикалящия свят са по-съвършени и страховете ни са по-сложни. Според психолозите, страхът е:

„Един от еволюционно наследените емоционални елементи ...,, който ни мобилизира" да се пазим от опасности (Goleman, 2011, p.15). Той е "отрицателно оцветена емоция, съпроводена от напрегнатост, чувство за непосредствена опасност за живота и разнообразни вегетативни нарушения". (Stoimenov, 2004, p. 970-971) Според психолозите типичните реакции са на агресия, бягство или прикриване, „замръзване" изпадане в ступор (Ciuti et all., 2012). Страхът има и социален план. В този план известният социолог Г. Фотев (Fotev, 2006) пише за социален страх. Според автора: „,... страхът, като социален страх е активен двигател на социализационния процес и е активен механизъм на социален контрол" (р.113). 
Поддаването на страха има тежки социални последици. Една от тях е наличието на агресия, която по психофизиологични причини е продукт на страха. В случая на COVID-19 пандемията c агресията се обясняват както активното желание и настояванията за бързо справяне с вируса, така и високата критичност, граничеща с недоверие към институциите. В личен план тази агресивност се пренася сред околните и в условията на социална изолация - това най-често са близките. Подпомагащ елемент е поведенческата неадекватност, предизвикана от опитите за преодоляване на психологическите последици от социалното изолиране чрез алкохол и медикаменти. Както казва представителят на СЗО за България, М. Околийски:

„Но има увеличаване на процента на хората, които злоупотребяват с медикаменти и алкохол. Най-вече мъжете злоупотребяват с алкохол, защото се опитват да се самолекуват от тревогата, която ги обзема. Жените по-скоро злоупотребяват с медикаменти. Тези феномени са подсилени поради пандемията, поради нуждата да се изолираме, да останем сами вкъщи" ("WHO: For the most part, Bulgarians trust medics about COVID-19", 2020).

От наблюденията в ежедневието на всекиго е известно, че и алкохолът, и злоупотребата с медикаменти променят поведенческата реакция в определени ситуации - депресивно настроение, раздразнителност, пиянска храброст, агресивност и т.н. Все предразполагащи към появата на насилие фактори (единият участник дразни, а другият реагира несьразмерно; единият излива страха си чрез насилие или единият трансформира страха си в предизвикателно дразнене). В ситуацията на настоящото справяне с пандемията, ако не съществуват объркването и страхът, няма да съществуват и въпросните фактори на междуличностно насилие.

В общ план предпоставките не са по-малко тревожни. Нищо не блокира мисълта, че агресивността може да се пренесе на мезо-групово социално равнище. Нещо повече - объркването при представянето на пандемичната обстановка пречи за „изработването на картината", която според У. Липман (Lippmann, 1965) стои между онова, което се случва в света и онова, което е в главата на хората. Тази пречка „разширява" в неподозирани измерения пейзажа на опасностите, които допълват водещия образ на страха от пандемията COVID-19. На агресивността, предизвикана от страха, отдаваме ниското доверие и склонността към скандали в COVID-19 ежедневието (вж. заглавията по-горе). 
В същото време човекът не е съвсем безпомощен пред страха. Страхът в различните си форми (тревожност, паника и т.н.) се овладява като се балансира с противотежестта на друга емоция и страст. Такива са надеждата и оптимизмът. Тази връзка е известна векове преди нас. В „Анатомия на страха. Трактат за храбростта" на испанския писател и философ Хосе Антонио Марина четем, че още Аристотел е казал:

„За да изпитва страх, човек трябва да изпитва надежда за спасение на онова, за което се тревожи" (Marina, 2010, p.16-17).

Според автора Б. Спиноза също намира надеждата за антагонист на страха и приема, че комплексът от двете страсти е решаващ за решаването на въпроси от етическо, политическо и религиозно естество (Marina, 2010, p. 16-17).

Близо да надеждата се нарежда и оптимизмът. Разликата между двете думи е тясна и в европейската традиция те често се спрягат като синоними. Надеждата е, че човек се надява в нещо малко вероятно да се случи, а оптимизмът е „стремеж към резултат в съчетание с увереността, че този резултат е по-вероятно да се случи отколкото не" (Bloeser \& Stahl, 2017). Обвързването на надеждата единствено с нисковероятните реализации отвежда в полето на психиатрията (Stoimenov, 2004, p. 551), тъй като крайните състояния на надежда и нереалистичен оптимизъм са свързани с пропускане на фактора „наличие на безперспективност". В случая на COVID-19 пандемията такава безперспективност отсъства, така че относно макро-социалното равнище на проявите, надеждата и оптимизмът са според разбирането на психолозите. Според тях надеждата е „вярата, че имаш възможността и способностите да постигнеш целите си, независимо какви са те" (Goleman, 2011, p. 98). Това я представя в светлината на мощен елемент от мотивите за нашето поведение. Както пише Д. Голман (Goleman, 2011) „надеждата означава, че човек няма да се остави на вълните на тревогата, на паникьорството или депресията в лицето на сериозни предизвикателства и дори на тежки поражения" (p.99), а тревожността и паниката са едни от многото лица на страха.

Ролята на оптимизма е близка: „Оптимизмът, подобно на надеждата, означава да очакваме, че като цяло всичко в живота ни ще бъде наред, въпреки пораженията и лишенията. От гледна точка на емоционалната интелигентност оптимизмът е умение, което спасява хората от апатията, безнадеждността или депресията в тежки моменти. Както и при надеждата - тази близка негова сродница - оптимизмът е важен инструмент за справяне с проблемите (стига, разбира се, да е реалистичен - твърде наивният оптимизъм може да бъде изключително разрушителен)" (р. 99-100). 
Според Мартин Селигман оптимизмът е свързан с увереността на личността в собствените ѝ способности, а от там и с мотивацията (р.99). Тази зависимост е съществена за успеха. В едно интервю А. Бандура представя тази връзка така:

„Способността не е някакъв неизменен предмет, който притежаваме; има огромна разлика между това как ще се представим днес и как - утре. Хората с чувство за лична ефикасност се изправят бързо след като са се спънали. Те подхождат към нещата с мисълта как да се справят с проблема, вместо да се притесняват за това какво може да се обърка" (p.101-102).

Ето защо оптимизмът и надеждата са необходими, особено в условията на пандемия.

\section{Пренасяне на страха в медиите и перспективи за развитие на проблематиката}

На фона на високата комплексност (недоверие, в смисъла даден от Н. Луман), напомнянето, че държавите и международните организации не са готови за посрещане на вирусни пандемии като тази от COVID-19, е прието като заплаха за живота и поражда естествен импулс за споделяне, което отвежда темата в традиционните вестници, радио, телевизия и в сайтовете им, както и в социалните онлайн платформи. Медиите не могат да не поемат този натиск, тъй като тяхната функция е да отразяват активно социалната действителност. В същото време са изправени пред предизвикателство, защото известното в медийните концепции за страха не е достатъчно.

Това не са познатите псевдоапокалиптични страхове от типа на „озоновата дупка неудържимо се разширява" или „ТИР се преобърна и войната по пътищата придоби нови размери". Страхът от коронавируса е специфичен. Той не се обвързва с физическото насилие, а с ужаса. Това е първичният страх за живота, в сравнение с което оставането без работа и ограничаването на свободата на придвижване са вторични елементи. По тази причина този страх трудно се вмества в неписаното правило, което в хипотезата си за страха Д. Пейчева предава с краткия израз: „добрата новина е лошата новина" (Peicheva, 2013, p. 209). Този страх е колкото осъзнат, толкова и безсъзнателен, но тук не става дума за аналитична психология, а за невъзможността да се помести в известни социологически медийни теории, като тази на Дж. Гербнер за култивирането (Peicheva, 2013, p. 91-105) или на А. Бандура за социалното научаване (Peicheva, 2013, p. 106-115). Той не е свързан само с живота на човека, а с живота на всички хора; не се предава с реалистични картини (защото те са в зоната на заразно болните) и в същото 
време е особено емоционален. Погледнато през концепцията на Д. Голман (Goleman, 2011) за емоционалната интелигентност, точно поради емоционалната интелигентност на съвременния човек този страх е заразен и бързо разпространим. Предава се с цифрите на представените статистики, чрез лицата и треперещия говор на репортерите и т.н. Този страх „продава" медийно съдържание, но едва ли е желан и от медиите, и от аудиторията. В случая ситуацията е относима към Хипотезата за страха на Д. Пейчева. В нея авторът пише:

„... когато страхът се конструира ежедневно и ежечасово от медиите и се представя като реален, и когато човек няма властта нито да го елиминира ,нито да преодолее затруднението от представяното равнище на знанията, може би е нещо повече от нормалното" (Peicheva, 2013, p. 231).

B COVID-19 пандемията не само обществото, но и самите медии са поставени в ситуация, още по-сложна от „нещо повече от нормалното", т.е. всички са в поширокото поле на неизвестност. Една от неизвестностите е в огледалната връзка страхнадежда. Решаването на този въпрос звучи актуално и по чисто биологични зависимости (все пак не всички стават жетва на вируси) - човечеството ще преживее коронавируса, колкото и да са разпространени конспиративните теории, а заедно с човечеството остават и обществото, и медиите.

Особеното в случая на пандемия е, че страхът достига до отделния представител на обществото и без вестник, телевизия, радио или сайт. На хората не им е необходимо да прочетат за катастрофа, за да усетят страха. При епидемии и пандемии те го виждат през опосредствания контакт, пренесен по опустялата улица, по затворените театри, музикални зали и т.н. Особеността е, че докато страхът се вижда навсякъде, надеждата изглежда се разпространява по друг начин. Ограниченията се налагат с централна заповед и във всички населени мета, докато новината за хубавото, новината, даваща оптимизъм, на макро ниво първо се разпространява от средство за масова комуникация. Следователно масмедиите са изправени пред предизвикателството не само да открият и заредят в новините емоцията с надежда, но и да направят така, че да има останали членове на аудиторията, които не очакват единствено страх от екрана или от страниците на вестника. В тази посока изпъква и другото предизвикателство за медиите преодоляването на отбелязаното от Н. Чомски, „социално отчуждаване".

Позитивната конотация в предложението за балансиране на нежелания страх с надежда и неотчуждаване вече се вижда в езика на някои политици. Пример е цитат от 
реч на премиер-министъра Б. Джонсън по повод пандемията: „Милиони хора трябва да си помагат един на друг. Аз искам да знаете, че правителството ще направи всичко, което може, за да помогне на вас и вашите семейства в това време" ("'This is the most prominent crisis of the generations". Boris Johnson's speech in full", 2020).

Друг пример отново е от Великобритания - едно от малкото обръщения на кралица Елизабет II, в която монархът казва: „Ние и преди сме се сблъсквали с предизвикателства, но сега е различно. Този път ние се обединихме с всички страни по света в общо дело, използвайки огромните достижения на науката и нашето инстинктивно чувство на състрадание и стремеж за изцеление. Ние ще постигнем успех и този успех ще принадлежи на всички ни" ("The Queen's coronavirus speech transcript: 'We will succeed and better days will come'", 2020).

Определено тези речи, а и заглавията около техния отзвук не звучат като „голия страх", който лъха от цитираните в началото съобщения: „Ако и други купят апарати за изкуствено дишане, няма да има оставени без помощ", „Обществото се провали" и т.н.

Аристотеловска логика или здрав разум? - в случая на пандемия - и двете.

\section{Заключение}

В ракурса на обществените отношения проличава, че пандемията, предизвикана от COVID-19, е криза с цивилизационен характер. Причината е, че тя повишава комплексността в обществото и променя доверието. Последиците при всички случаи засягат не само здравето на хората, но и налагат преосмисляне на бъдещите приоритети. Един от тези приоритети е балансът между неолиберализма и политиките за регулиране на отношенията между хората.

Усещането, че цивилизацията е подценила опасността от биологична запалха, примесено с повишената усложненост на взаимодействието между институции и хора, е източник на първичен страх. Този страх не е конструктивен.

Колкото и странно да изглежда, негова проява са конспиративинте теории, които също са деконструктивни в социално отношение, тъй като са само едно своеобразно бягство от страха.

Перспективата за развитие на кризата е свързана с акцентиране върху психологическия баланс от връзка между страх, надежда и оптимизъм, а медиите са натоварени с отговорна роля за реализирането на този акцент. 


\section{Използвана литература}

Atanasov, P. (2020). COVID -19 - sluhove, falshivi novini i Shirokata sigurnost [COVID 19 rumours, fake news and wide security]. In N. Dojkov (Ed.), Sbornik nauchni trudove, Mezhdunarodna nauchna konferencya „Shirokata sigurnost", t. 2. Kibersigurnost. ikonomicheska, socialna $i$ kulturna sigurnost [Proceedings of the international scientific conference "Wide security" (Vol.2)]. (pp. 496-505). NBU.

Atanasov, P. (2017). Myasto i rolya na internet pri izgrazhdaneto na socialna percepciya [Place and role of internet in building social perception]. In D. Pejcheva, V. Milenkova, (Eds.), Digitalizaciya i socialni transformacii [Digitalization and social transformation]. (pp.158-166). Universitetsko izdatelstvo „N. Rilski".

Attali, J. (2020, March 19). What will Covid-19 give birth to? Jaques Attali - blog. http://www.attali.com/en/society/what-will-covid-19-give-birth-to/

Bandura, A. (1978). Asocial learning theory of aggression. Journal of Communication, 28(3), 12-29. DOI: 10.1111/j.1460-2466.1978.tb01621.x

Bloeser, C. \& Stahl, T. (2017). Hope. In E. N. Zalta, (Ed.), The Stanford Encyclopedia of Philosophy. https://plato.stanford.edu/archives/spr2017/entries/hope/

Chekalin, Yu. (2020, May 01). Interviu s Noamom Homskim [Interview with Noam Chomsky]. Fitzroy. https://fitzroymag.com/mir/intervju-s-noamom-homskim/

Ciuti, S., Northrup, J. M., Muhly, T. B., Simi, S., Musiani, M., Pitt, J. A. \& Boyce, M. S. (2012). Effects of humans on behavior of wildlife exceed those of natural predators in a landscape of fear. PLoS ONE, 7(11). doi: 10.1371/journal.pone.0050611

Dots. Okolijski: $37 \%$ ot balgarite ne iskat da badat vaksinirani sreshchu COVID-19. Spored nego prichinite se korenyat vav falshivi vyarvaniya i konspirativni teorii. (2020, November 10). [Assoc. Prof. Okoliiski, "37\% of Bulgarians do not want to be vaccinated against COVID-19." According to him, this results from false beliefs and conspiracy theories]. BTV News. https://btvnovinite.bg/predavania/tazi-sutrin/dookolijski-v.html

D-r Branzalov: Falshivi bolnichni lista nyama. (2020, February 18). [D-r Branzalov: Fake sick leave no]. Balgarski lekarski sayuz (BLS). https://www.credoweb.bg/publication/119391/d-r-n-branzalov-falshivi-bolnichni-listanyama

Dzhonev, S. (2013). Socialna psihologiya, t. 3 [Social Psychology (Vol. 3)]. SOFI-R Publishing house 
Ely, J. W. Jr. (1992). The guardian of every other right: A constitutional history of property rights. Oxford University Press.

„Eto krupnejshij krizis pokoleniya". Polnyj tekst rechi Borisa Dzhonsona o koronaviruse.(2020, March 13). ["This is the most prominent crisis of the generations". Boris Johnson's speech in full]. Kommersant'. https://www.kommersant.uk/articles/eto-krupneyshiy-krizispokoleniya-polnyy-tekstrechi-borisa-dzhonsona-o-koronaviruse

Fotev, G. (2006). Sociologiya na straha [Sociology of Fear]. Iztok-Zapad

Gaus, G., Courtland, S. D. \& Schmidtz, D. (1996). Liberalism. In E. N. Zalta (Ed.), The Stanford Encyclopedia of Philosophy.

<https://plato.stanford.edu/archives/fall2020/entries/liberalism/>

Goleman. D. (2011). Emocionalnata inteligentnost [Emotional Intelligence]. Iztok-Zapad.

Ivajlo Penchev: Ako i drugi kupyat aparati za izkustveno dishane, nyama da ima ostaveni bez pomoshch. (2020, March 18). [Ivajlo Penchev: If others purchase respirators too, everyone will be taken care of]. BTV Novini [BTV News]. https://btvnovinite.bg/predavania/lice-v-lice/ivajlo-penchev-ako-i-drugi-kupjataparati-za-izkustveno-dishane-njama-da-ima-ostaveni-bez-pomosht.html

Kirov, N. (2020a, July 01). USA izkupiha vsichkiya „Remdesivir" za Covid-19. Te shte poluchat vsichki brojki, proizvedeni prez yuli. [USA bought out Remdesivir and will receive all units manufactured in July] Vesti.bg. https://www.vesti.bg/temi-vrazvitie/tema-koronavirus/sasht-izkupiha-vsichkiia-remdesivir-za-kovid-19-6111713

Kirov, N. (2020b, August 29). Hilyadi v London: Covid-19 e konspiraciya. Spored protestirashchite maskite namalyavat imuniteta. [Thousands of people in London: COVID-19 is a conspiracy. The protesters claim that masks lower the immunity] Vesti bg. https://www.vesti.bg/temi-v-razvitie/tema-koronavirus/hiliadi-vlondon-covid-19-ekonspiraciia-6114180

Kirov, N. (2020c, August 30). Opit za shturm na Rajhstaga, stotici arestuvani. [Attempted charge against the Reichstag, hundreds arrested]. Vesti bg. https://www.vesti.bg/temiv-razvitie/tema-koronavirus/opit-za-shturm-na-rajhstaga-stotici-arestuvani-6114189

Lippman, W. (1965). Public opinion. Free Press. (Original work published 1922)

Luhmann, N. (1968/2014). Vertrauen: ein mechanismus der reduktion sozialer komplexität [The trust: a mechanism for reduction of social complexity]. $\left(5^{\text {th }}\right.$ ed.) UTB GmbH. 
Marina, J. A. (2010). Anatomiya straha. Traktat o hrabrosti [Anatomy of Fear. A Treatise on Courage]. Astrel.

Moller, A. P. \& Nielsen, J. T. (2010). Fear screams and adaptation to avoid imminent death: effects of genetic variation and predation. Ethology Ecology \& Evolution, 22(2), $183-$ 202. DOI: $10.1080 / 03949371003707968$

Panicidis, H., Kasabov, O. \& Popivanov, B. (Eds.). (2016). Idei za grazhdanskoto obshchestvo. Klasicheski tekstove. Antologiya [Ideas for Civil society. Classic Texts. Anthology]. Universitetsko izdatelstvo Sv. Kl. Ohridski.

Pearce, K. (2019, November 06). Pandemic simulation exercise spotlights massive preparedness gap. Event 201, hosted by the Johns Hopkins Center for Health Security, envisions a fast-spreading coronavirus with a devastating impact. JHU Hub. https://hub.jhu.edu/2019/11/06/event-201-health-security/

Peicheva, D. (2013). Masmediynoto vazdeystvie [Massmedia effects]. Universitetsko izdatelstvo „N. Rilski".

Schwab, K. (2016). Chetvertaya promyshlennaya revolyuciya [The Fourth Industrial Revolution]. Eksmo.

Seligman, M. (1975). Helplessness: on depression, development and death. Freeman.

Shefat na BLS za Covid-19: Obshchestvoto se provali [Head of the Bulgarian Medical Union: Society failed]. (2020, November 09). Vesti.bg. https://www.vesti.bg/temi-vrazvitie/tema-koronavirus/lerkar-nie-sme-v-situaciiata-opisana-ot-d-r-mutafchijski6117360

Signali za lipsa na „Remdesevir" v bolnicite v Sofiya i Vraca [Reports of shortage of Remdesivir in hospitals in Sofia and Vratsa]. (2020, November 7). BTV News. https://btvnovinite.bg/bulgaria/signali-za-lipsa-na-remdesivir-v-bolnicite-v-sofija-ivraca.html

Skandal s daryavaneto na kravna plazma za COVID-19 [Scandal with the donation of blood plasma for COVID-19]. (2020, November 09). Vesti.bg. https://www.vesti.bg/temi-vrazvitie/tema-koronavirus/skandal-s-dariavaneto-na-kryvna-plazma-za-kovid-196117358

Sled varnato darenie: ot „uoltopiya" uvelichiha sumata $i$ broya na aparatite [After the returned donation, "Utopia" bumps up the amount of money and the machines]. (2020, March 17). BTV News. https://btvnovinite.bg/bulgaria/sled-varnato-darenie.html 
Sociolog: Balgarite sa razdeleni otnosno merkite za COVID-19 [Sociologist: The Bulgarians are divided about COVID-19 measures]. (2020, November 04). Vesti.bg. https://www.vesti.bg/temi-v-razvitie/tema-koronavirus/sociolog-bylgarite-sarazdeleni-otnosno-merkite-za-covid-19-6117170

Stepanova, A. (2020, October 28). Zlodej dlya konspirologov, filantrop, vtoroj v spiske Forbes. Billu Gejtsu — 65 let [Conspirologists' villain, philanthropist, second in Forbes list. Bill Gates-65 Years]. TASS. https://tass.ru/ekonomika/9829233

Stoimenov, J., Stoimenova, M., Koeva, P., Koev, G., Popov P. \& Stoimenova, L. (2004). Psihiatrichen enciklopedichen rechnik [Encyclopaedic Guide to Psychiatry]. BAS Publishing house "M. Drinov".

SZO: Balgarite v golyama stepen vyarvat na medicite za COVID-19 [WHO: For the most part, Bulgarians trust medics about COVID-19]. (2020, October 28). Novini.bg. https://novini.bg/zdrave/bolesti/626386

The Bulgarians' attitude towards COVID-19 and conspiracy theories - June. (2020). TREND. Retrieved June, 2020 from https://rctrend.bg/project//нагласи-на-българите-спрямоконспира/

The Queen's coronavirus speech transcript: 'We will succeed and better days will come'. (2020, April 05). The Telegraph.

https://www.telegraph.co.uk/news/2020/04/05/queens-coronavirus-speech-full-willsucceed-better-days-will/ 